\title{
Economics
}

2021; 10(1): 21-27

http://www.sciencepublishinggroup.com/j/eco

doi: 10.11648/j.eco.20211001.13

ISSN: 2376-659X (Print); ISSN: 2376-6603 (Online)

\section{The Paradox of Money in Politics: When Businessmen Choose to Be Politicians}

\author{
Heba Mohamed Zahra \\ Department of Political Science, Faculty of Economics and Political Science, Cairo University, Giza, Egypt \\ Email address: \\ hmzahra@cu.edu.eg \\ To cite this article: \\ Heba Mohamed Zahra. The Paradox of Money in Politics: When Businessmen Choose to Be Politicians. Economics. \\ Vol. 10, No. 1, 2021, pp. 21-27. doi: 10.11648/j.eco.20211001.13
}

Received: January 5, 2021; Accepted: January 26, 2021; Published: February 2, 2021

\begin{abstract}
This research paper highlights the link between economics and politics through exploring the controversial phenomenon of money in politics. Using the theoretical framework that highlights the importance of the multinational corporations in global politics as well as the structural relationship between the state and businessmen, this paper starts to analyze the complexity of this phenomenon. Most of the scholarly work emphasized the negative consequences of this phenomenon and a few showed that it could result in mixed outcomes. A number of scholars went beyond these results to show us the real paradox or dilemma about money in politics. Money was indispensable to electoral campaigns that informed voters in spite of any problems that money could cause. In addition, money had an impact on the democratic process, although this impact differed from a country to another. Then the paper highlights one of the most famous and perplexing manifestations of money in politics in today's world which is the willingness of businessmen to run for elections as candidates who seek office as legislators or executives. This desire to occupy a governmental position made scholars keen to explain the convenient environmental conditions for this to take place, the popular support for businessmen candidates and the motive behind this. The paper concludes the persistence of this paradox and recommends the necessity of collaboration between economic and political researchers in order to investigate this dilemma and further explain the conditions related to businessmen who reach office.
\end{abstract}

Keywords: Business, Politics, Elections, Structural Relationship, Public Opinion

\section{Introduction}

Scholars realized the inherent link between politics and economics; hence the interdisciplinary field of political economy flourished. This link was strongly proved not only in theoretical and academic debates, but also in real life. Specialists in this interdisciplinary field found the phenomenon of money in politics to be rather intriguing. Delving into this phenomenon revealed the persistence of one of the manifestations of money in politics i.e. the willingness of businessmen to hold political office through winning elections. Although this phenomenon might seem rather recent, some evidence proved that it was not.

Grunewald wrote, more than half a century ago, an article entitled "Businessmen must get active in politics". He highlighted the importance of the decisions and policies of any government which necessitated the presence of qualified persons to hold political positions. Businessmen should feel the importance of working for the government with full potential, because this would be beneficial to them. The governmental decisions and policies regulated and affected business and this should push businessmen to realize the importance of becoming a part of government. Otherwise, other sectors of the society would think of doing this and would have a role in formulating government policies in a way that wouldn't fully meet the goals of businessmen. It is worth mentioning that Grunewald knew that businessmen could influence political decisions, either through interfering indirectly by employing tactics such as helping the appropriate candidate win through offering funds to his campaign or sometimes directly through joining a political party, or thinking of appropriate candidates, or seeking office themselves. [1]

This paper seeks to discover this link between politics and economics through examining the influence that money has on the political life, so the next section will present the 
theoretical framework that explains this phenomenon. The third section presents the scholarly contributions that show the type of impact money has on the political life in different countries. The fourth section analyzes the paradox of money in politics. Then the fifth section explores a specific prominent manifestation of the phenomenon of money in politics in our world i.e. the willingness of businessmen to run for elections as candidates seeking to hold legislative or executive positions. This paper ends with the conclusion and recommendations for future research.

\section{Theoretical Framework: The Inherent Link Between Economics and Politics}

\subsection{The Clear Link Between States and Multinational Corporations}

Although some scholars did not pay attention to the importance of the relationship between economics and politics, in the 1990s, Susan Strange recommended that researchers who were interested in studying the political phenomena in the international arena needed to pay attention to the critical role of the multinational corporations, in an attempt to clarify the interaction between two actors: the states and multinational corporations.

Her recommendation was accompanied by an accusation to researchers who studied international relations of being "Flat Earthers", and other scholars like Babic and his colleagues wrote to join her in her call. They further believed in the importance of analyzing the role of multinational corporations as international actors. They acknowledged the significance and the role of these corporations. They realized that these companies could act as instruments in the hands of the state that let them extend their influence into the economies of other countries. On the other hand, multinational corporations knew how to use the state for their own benefit, as they made use of tax havens. They invited scholars to abandon the vision that states were much more important than these corporations. According to them, the new perception should be "that corporations and states are juxtaposed actors in an international environment that exercise power over each other in specific spatiotemporal settings." [2]

Actually this call is really significant as specialists in the fields of management and economics have always made a clear distinction between corporations and state agencies as the first is a principal economic actor and the second is the political actor. Some management scholars like Scherer and Palazzo wrote a decade ago recommending that this perception should change due to the globalization process and saw that this clear distinction was not relevant anymore. They clarified that the mission of corporations had extended to include some social and political dimensions. They introduced the term "political CSR" where CSR stands for "corporate social responsibility" in which the corporations will have a clear role in "global regulation and providing public goods." Their research paper was an invitation to adopt a broad perspective while studying global politics, in which a close cooperation exists between both civil society and corporations to take part in shaping the rules that governed both the political and economic domains. [3]

After realizing the critical link between states and firms, it is important to refer to Zingales' contribution entitled: "Towards a Political Theory of the Firm" that will add to our theoretical framework. Zingales differentiated between rival firms in the market: as those that had market power and those that didn't. The first category of firms could exert some pressure on politicians to get what they aimed at, but the other firms couldn't. When the effective firms succeeded in achieving their goals by exerting pressure over the political system, their market power would increase and opportunities of their competitors would diminish and so on.

Zingales elaborated further on the relationship between the state and firms in terms of the strength of each actor vis-à-vis the other and drew the attention of researchers to the importance of preserving the balance between the two actors. He showed that the weakness of the state would reduce its capacity to preserve property rights which would be unacceptable to firms that would either leave business or use violence to preserve their own property. On the other hand, the strength of the state might lead it to take resources from the firms instead of preserving their rights. Therefore, if we saw the situation the other way round, the weak firm that faced a strong state would suffer from the loss of its resources to the state which could reach the extent of expropriation by the state. A strong firm that faced a weak state would impose its will concerning property rights in a way that benefitted it and jeopardized the interests of the population. [4] This theoretical contribution of Zingales' in addition to other scholars proved the presence of a clear link between the state and the corporations and encouraged scholars to study the nature of this relationship.

\subsection{The Nature of the Relationship Between the State and Businessmen}

One of the very recent theoretical contributions that helped scholars understand the nature of the relationship between the political and economic domains examined the instrumental and the structural power of the economic interest groups. Tasha Fairfield explained these concepts in her book "Private Wealth and Public Revenue in Latin America: Business Power and Tax Politics" published in 2015. The instrumental power focused on the links between economic interest groups and politicians, whether formal or informal, in addition to the factors that empowered these business organizations such as their financial power or their close relationship with the media. On the other hand, Fairfield referred to the structural power saying that it "stems from the policymakers' expectations about the consequences of their policies on investment decisions". [5]

A more comprehensive theory was presented by Jerome Roos in his book "Why Not Default? The Political Economy of Sovereign Debt" published in 2019. One of the main ideas that Roos discussed in this important book was the nature of 
the relationship between businessmen and the state. Roos asked his readers to try to answer the question "how the modern state is financed." He suggested that "public spending ....can only be sustained in the long run by collecting taxes and borrowing funds from private hands". So anyone who would like to explain the relationship between the state and capitalists should acknowledge the importance of both paying taxes and public debt.

In order to explain his theory, Roos referred to the American sociologist James O'Connor who wrote an important book "The Fiscal Crisis of the State" in which he analyzed the inherent problem with the functions of the state "legitimation" and "accumulation". The state needed legitimacy so as not to lose popular support and it needed capital accumulation to gain enough resources. This constituted the dilemma that the state faced: it needed to increase spending to gain popular support and legitimacy but it couldn't impose more taxes on businessmen to help them work and produce more. So the consequence of this situation would be "a fiscal crisis of the state." The end result of this situation would be a negative impact on both the legitimacy and capital accumulation.

Hence, Roos was able to explain his theory which showed that the state was "structurally dependent" on capitalists to perform its various functions. This created a link between the state and capitalists and had a negative impact on the independence of the state. On the other hand, those who possessed economic power depended on the state that imposed various regulations related to market and property. This helped Roos reach the significant conclusion that: " It is the state's structural dependence on credit - and, indeed, the wider economy's structural dependence on credit- that ultimately endows finance with the unique form of power it wields under capitalism: structural power."

Roos illustrated that "structural power," according to him, was completely different from instrumental power. When businessmen decided to finance the electoral campaign or even to reach government office through elections, this could be referred to as instrumental power. Roos explained to us that structural power worked differently and it did not necessarily require this clear impact on political life. To make his idea clearer, he defined this concept as "the capacity to withhold something upon which another depends." In other words, it is "the power to punish by not doing". Therefore, finance had this structural power over politics and even ordinary families by means of having the capacity to deny credit if those who needed it did not act according to its interests. However, there was another face for this structural power, for this credit was needed by states, enterprises and families and those who provided credit needed "a steady stream of interest payments to thrive in a competitive marketplace." [6]

Using the components of this theoretical framework, this paper will investigate the role of money in politics and the willingness of businessmen to run for elections.

\section{The Impact of Money on the Political Life}

\subsection{The Conventional Wisdom: A Predominantly Negative Impact}

Some researchers chose to analyze the problem of money in politics and its necessity as well as consequences. Tham was one of the scholars who believed in the dangerous role that money played in the political life. He showed that members of parliament in charge of legislation belonged to political parties and these parties needed to finance their activities which made them somehow subordinate to the power of businessmen. This enhanced the presence and influence of businessmen in politics. A rather influential and repeated statement belonged to Lindblom and was repeated by various theorists: 'businessmen cannot be left knocking at the doors of the political systems, they must be invited in.' So there was an accusation that the capitalist economic system stood behind the corruption of democratic regimes that prioritized the role of legislators. According to Tham, this led to the introduction of the term 'clientelism' which origin was 'an office holder's dependence on the financial support of a wealthy patron to a degree that is apt to compromise the expectation, fundamental to representative democracy, that public power will be exercised in the public interest.' [7] This view showed how pessimistic and skeptical some theorists were of the negative influence of money on the quality of democracy.

Various case studies proved that observers were right when they were skeptical of the consequences of the close link between money and politics and how this impact could be detrimental. The Malaysian case was a repeated case studied by scholars to prove that when money interfered in politics, the end result would be corruption. Gomez analyzed how funds dedicated to political parties in an unequal fashion affected the results of elections. Money was also interrelated with politics in the form of the belief of the political parties in the necessity to have their own enterprises, a phenomenon that could be called "political business". The political impact of money reached the extent of manipulating it by political leaders to gain the endorsement of grassroots which made people feel that they couldn't trust influential government officials. [8]

Mutalib was another scholar intrigued by the situation in Malaysia, so he referred to money politics as a tumor in spite of the economic growth in the country. Efforts were exerted by the prime minister to enhance business ethics in addition to restructuring the Supreme Council of the "dominant Malay ethnic party United Malays National Organization". Moreover, the government presented an initiative to combat political corruption. The author tried to prove that the devastating impact of money politics in Malaysia was there for a long time. The study reached the pessimistic conclusion that this disease was deeply entrenched in the country long ago that it would make it difficult for any prime minister to defeat it. The recommendation of this study was to focus on 
the culture of the people and try to modify certain dimensions of it. Mutalib also emphasized the significant role of the political will in order to deal with this problem. [9]

In a rather warning analysis, Clark and Walton studied the same problem in Papua New Guinea and were able to prove that money politics was widespread and not related to elections only, but was actually entrenched in the institutions of government which made them introduce the concept "the institutionalization of money politics." People and different reports realized how money corrupted elections, bought votes and bribed election officials. This phenomenon was not only clear in elections, but in state administration in general. The government declared its support to the anti-corruption efforts; however, it did not allow enough funds to the institutions entitled with the task of combating corruption. Although the country adopted laws that could combat corruption, it did not properly execute these laws. [10]

Some scholars analyzed this negative impact in a way that showed that dealing with this problem was so difficult. Bowornwathana was one of these scholars who held this view while discussing the effect of having big businessmen at the top of the government apparatus for several reasons such as: the influence and the entrenchment of big businessmen in political life, in addition to their major influence on the state institutions among which were the institutions that fought corruption. Moreover, big businessmen could escape all anti-corruption efforts by means of using their office when they reached power to enhance their economic power. [11]

\subsection{A Mixed Impact}

Amid all the studies that proved the validity of the conventional wisdom, very few of them reflected a rather optimistic view about the impact of the collaboration between money and politics. Matsumoto used Taiwan as a case in point to prove that the negative impact of the money in politics could yield later on positive results. Matsumoto explained that the enterprises that the ruling party KMT owned actually helped it stay in power which assisted the party in its endeavor to push for democratization. This financial power also granted the party chairman Lee Teng-hui the ability to demonstrate himself as a powerful leader and this helped his democratization project. However, it is worth mentioning that this had a negative impact on the long run; as it made the phenomenon of money politics (a feature of authoritarianism) survive even with the efforts to achieve democratization. In addition, any economic problems that happened within these enterprises would affect the whole economy of the country. [12] This study clarified that even when a person was optimistic about the impact of money, still negative consequences would appear.

After discussing both the conventional wisdom and the positive view that tries to see light at the end of the tunnel, it becomes clear that money in politics is a double-edged sword i.e. in a few cases beneficial and most of the time dangerous. So there is a clear paradox of money in politics.

\section{The Paradox of Money in Politics}

Analyzing the impact of money in politics reveals the paradox or dilemma since the effect of money on politics is never uniform. This phenomenon continues to be perplexing even with the various contributions that analyzed it. Actually, one may doubt that the contributions of scholars somehow lead to more confusion.

\subsection{Money Influences the Political Fate Differently Within the Same Region}

The prominent political scientist Lucian Pye wrote about this phenomenon and concluded that surprisingly in East Asia money politics enhanced democratization clearly in Japan and Korea and less clearly in Taiwan. However, this was not the case in countries like Singapore and China. He noticed that in that region the distinction between the political and economic realms as well as the private and public realms could not be clearly detected. So the Japanese and South Korean leaders could easily interact with the private sector and their care about money had led them to develop costbenefit thinking. They now moved towards "a politics of calculated interests and pragmatic considerations, which constitute the foundations of democratic politics." [13] Pye was able to prove that even within the same region; the impact of money on the democratic process would differ from a country to the other.

\subsection{Money Is Indispensable to Democracies Despite Its Harmful Consequences}

The paradox of money in politics was emphasized by Bailey who focused on the role of money in electoral campaigns and perceived it as important since campaigns enlightened ordinary people and provided them with necessary information. However, the main shortcoming that some observers suggested was that allowing wealthy individuals to share in financing campaigns would make candidates keen to promote the interests of wealthy people not the general population. Bailey wrote to recommend reforms that promoted the informative function of the electoral campaigns and let the donations to electoral campaigns be from various sources.

Bailey recognized the positive role of money in electoral campaigns which was represented in the informative function, otherwise ordinary citizens wouldn't know about candidates. Although, some believed that the information that voters got from campaigns was not always totally true, however, performing the informative function could guarantee the participation of voters in the electoral process. Bailey recognized that devoting money to electoral campaigns helped voters know how each candidate represented a particular ideology. The conclusion was that money truly could divert public policy away from public good, however democracies could not do without it because of the informative and mobilization functions of campaigns. [14] 


\subsection{Financial Resources Owned by Political Parties Could Be Either Beneficial or Harmful to the State}

One of the most interesting attempts to explain this paradox did not discuss money in electoral campaigns, but with regards to the phenomenon (Parbus) "party-owned forprofit business". It represented a mix of two types of power: the political and the economic, which was a new phenomenon. Some could be optimistic and others could be pessimistic regarding it. The pessimistic ones would perceive this as an implicit way to get hold over public property in poor countries torn by conflict.

But the optimistic vision perceived this business as an effective 'third way' that can deal with the economic problems that resulted from the performance of both the market and the government. So this business provided the party in power with enough money to achieve progress and preserve legitimacy. [15]

At the end of this section, it is clear that Roos was correct when he described the relationship between the state and the capitalists as a structural one. Each side needs the other and each side can punish the other by refraining from carrying out its duty towards it.

\section{A Manifestation of Money in Politics: Businessmen Running for Elections}

After discussing the paradox of money in politics and the various dimensions of this phenomenon, this paper will seek to clarify one of the most attractive manifestations of money in politics, i.e. businessmen who choose to be politicians by nominating themselves as candidates who run for elections and win legislative or executive positions. This phenomenon takes place in both highly developed and underdeveloped countries and raises the following question: Why do these wealthy individuals who care most about the economy think of holding political positions in the legislative or the executive authority?

\subsection{The Suitable Environment}

Some scholars helped us understand what the necessary conditions that led this phenomenon to flourish were. Gehlbach, Sonin and Zhuravskaya explained this phenomenon by focusing on the status of the institutional environment. They suggested that when voters had the power to oversee the performance of the elected government officials, businessmen would feel they didn't have enough privileges so they would not be encouraged to run for elections. The dominance of ineffective institutions helped businessmen realize they could achieve their interests whether they became government officials or not, but they would think of running for elections so as not to carry the burden of trying to influence government officials. These scholars were able to prove the validity of their argument by studying the gubernatorial elections in Russia. They noticed that businessmen ran for elections in areas in which there were restrictions on media and skepticism about the level of transparency of the government institutions. [16]

In a rather specific case study, Neumeier wrote in 2018 about state governors in the USA who were originally businessmen, more specifically CEOs. This study found that these businessmen sought to reach this political position when the country had economic problems. The second finding was that these governors with economic background achieved "a 0.5 percentage points (pp.) higher annual income growth rate, a $0.4 \mathrm{pp}$. higher growth rate of the private capital stock, and a $0.6 \mathrm{pp}$. lower unemployment rate than" the achievements of governors who didn't serve before as CEOs. In addition, the longer their tenure was, the more positive influence they had on the market [17].

There is a clear contradiction between the opinions of scholars concerning the environmental and institutional conditions. Some results referred to the presence of this phenomenon in an authoritarian context and others referred to its existence in a consolidated democracy such as the USA. Actually in our real world, it is found in both contexts.

\subsection{The Public Support}

Other scholars interested in public opinion analyzed the opinions of voters when they were faced with businessmen running as candidates in elections. For American voters, businessmen candidates were not the ones who won the lion's share of votes, as voters were inclined to support other candidates who ran for elections before or candidates who had some other practical background like sharing in school board. The results also showed that voters would support small businessmen more than someone who only declared himself as a businessman, as Americans tend not to trust large enterprises. Moreover, the results showed that republicans tended to vote for businessmen candidates (in general) more than democrats. However, when it came to small businessmen candidates these partisan differences didn't occur. [18]

American voters were not the only voters who seemed to be important to public opinion scholars. Scholars studied the inclinations of British voters in an attempt to clarify their stance regarding rich candidates. A study showed that voters would rather endorse "self-made businessmen to financiers, but that regardless of occupation they reacted negatively to financial success." Some sectors of the society were clearly against the rich candidates such as women, and working class. The scholars saw that their study proved the validity of identity politics i.e. voters needed to feel they voted for someone who had many common features with them. One of the interesting results of this study was that voters were against rich candidates. However, the scholars were flexible enough to suggest that these results could be affected by the British context and the big financial crisis, which meant that other studies that examined different contexts or times could yield different results. [19]

A third example was a research that focused on measuring the public opinion of students in two developed countries: the USA and New Zealand when it came to voting for candidates 
according to two main characteristics: the occupation and gender. The results here were interesting as students saw they would endorse specialists of each area to deal with problems in that particular area. According to them, it'd be better to vote for someone with a political background to find the best solutions in dealing with the security and strategic issues. Voting for a businessman would be the best option to solve pressing economic problems. A candidate with an experience in education would deal most effectively with human services matters. However, students of the two countries differed with regards to the possibility of voting for someone based on his occupation. It is worth mentioning that in the case of students from New Zealand they preferred to vote for candidates with political expertise than for businessmen. [20]

\subsection{The Motive to Get Elected}

Recognizing the reason behind the willingness of businessmen to run for elections is intriguing. Bunkanwanicha and Wiwattanakantang tried to give us a clue about the answer to this question by applying it to Thailand. "The more business owners rely on government concessions or the wealthier they are, the more likely they are to run for top office. Once in power, the market valuation of their firms increases dramatically." By means of their positions, these businessmen in government could adopt policies and regulations that served their economic interests. Such policies would be harmful to their rivals on the national and international levels. So in economic terms, the companies of these big businessmen gained "more market share."

This study proved that big businessmen who had business relations with the government would always seek to run for elections. The authors also suggested that their results were not restricted to the Thai case and would probably apply to countries whose economies were starting to develop and the instruments of overseeing the functions of the different branches of government were not working effectively. Also this could apply to states suffering from instability and corruption and to countries whose political leaders had economic interests that could be further enhanced using the government powers. [21]

These significant results didn't show why businessmen would seek public office in consolidated democracies.

\section{Conclusion}

The dilemma of money in politics is one of the problems of modern life that scholars could not ignore. It pushed them to acknowledge the presence of an unbreakable chain between politics and economics. Theorists felt they had the mission of drawing the attention of scholars and observers to the importance of multinational corporations in world politics. One of the most recent theories even described the relationship between states and businessmen as a structural relationship where every side couldn't do without the other. Academic research proved the fears of many observers who noticed that money could corrupt the electoral process and the political process in general. Very few researchers noticed a mixture between good and bad effects of money in politics. Therefore, this paper realized that the effect of money in politics was a real paradox in which money was significant in the electoral process and democracy in general despite its clear shortcomings.

Then the paper tried to delve into a specific and important manifestation of money in politics that took place in consolidated democracies as well as in authoritarian and semi-authoritarian regimes i.e. the businessmen who sought to run for office. Scholars were divided on the particular circumstances that helped this occur. The results of some indicated that this would happen in countries that had weak institutions. While others discussed this phenomenon in the USA which is a consolidated democracy, so the results were rather contradictory. The paper also discussed the popular support to businessmen and showed that they were not always strongly supported by voters. As for the motive, scholars tried to prove that this took place because of the mentality of the businessman who knew that the political power would be a great asset that served his economic interests. However, observers noticed that businessmen sought political positions in consolidated democracies as well as in authoritarian and semi-authoritarian regimes which could be considered a dilemma.

\section{Recommendations}

This paper proves that in spite of all the scholarly work dedicated to discuss the phenomenon of money in politics, there are several aspects of the topic that are still controversial. A better collaboration between economic and political researchers is needed to reach better conclusions concerning some aspects. The first is the crucial role of money in electoral campaigns despite its dangerous consequences on democracies. The second is the effect of money on the democratization process which differs from a country to another. The third is the environment that helps businessmen run for elections and what their motives are especially in highly developed countries.

\section{References}

[1] Grunewald, D. (1965). Businessmen Must Get Active in Politics. The Academy of Management Journal, 8 (1): 50-52.

[2] Babic, M., Fichtner, J. and Heemskerk, E. M. (2017). States versus Corporations: Rethinking the Power of Business in International Politics. The International Spectator, 52 (4): 20 43.

[3] Scherer, A. G. and Palazzo, G. (2011). The New Political Role of Business in a Globalized World: A Review of a New Perspective on CSR and its Implications for the Firm, Governance, and Democracy. Journal of Management Studies, 48 (4): 899-931.

[4] L. Zingales, "Towards A Political Theory of the Firm," NBER Working Paper Series, Working Paper 23593, National Bureau of Economic Research, Massachusetts, July 2017. 
[5] Castaneda, N. (2016). Book Review: Tasha Fairfield, Private Wealth and Public Revenue in Latin America: Business Power and Tax Politics (New York, Cambridge University Press, 2015). Journal of Latin American Studies, 48 (4): 886-887.

[6] J. Roos, Why Not Default? The Political Economy of Sovereign Debt. Princeton: Princeton University Press, 2019.

[7] Tham, J. - C. (2019). Democracy before Dollars. AQ: Australian Quarterly, 90 (2): 20-32.

[8] Gomez, E. T. (2012). Monetizing Politics: Financing Parties and Elections in Malaysia. Modern Asian Studies, 46 (5): $1370-1397$.

[9] Mutalib, H. M. (2017). The Other Side of Malaysia's Enviable Economic and Multiethnic Stability: The Obstinate Resilience of 'Money Politics'. Asian Ethnicity, 18 (1): 54-73.

[10] Clark, L. and Walton, G. W. (2017). Drivers of Electoral and Institutional Money Politics in Papua New Guinea. Australian Journal of Asian Law, 18 (2), Article 4: 1-13.

[11] B. Bowornwathana, "The Politics of Combating Corruption when Big Businessmen are at the Helm: Lessons from Thaksin and Berlusconi," in The Many Faces of Public Management Reform in the Asia-Pacific Region, Research in Public Policy Analysis and Management, vol. 18, C. Wescott, B. Bowornwathana and L. R. Jones, Eds. UK: Emerald Group Publishing Limited, 2009, pp. 73-96.

[12] Matsumoto, M. (2002). Political Democratization and KMT Party-Owned Enterprises in Taiwan. The Developing Economies, XL-3: 359-380.
[13] Pye, L. W. (1997). Money Politics and Transitions to Democracy in East Asia. Asian Survey, 37 (3): 213-228.

[14] Bailey, M. (2004). The Two Sides of Money in Politics: A Synthesis and Framework. Election Law Journal, 3 (4): 653669.

[15] B. Abegaz, "Political Parties in Business," The College of William and Mary, Department of Economics, Working Paper Number 113, April 2011.

[16] Gehlbach, S., Sonin, K. and Zhuravskaya, E. (2010). Businessman Candidates. American Journal of Political Science, 54 (3): 718-736.

[17] Neumeier, F. (2018). Do Businessmen Make Good Governors? Economic Inquiry, 56 (4): 2116-2136.

[18] Adams, B. E., Lascher Jr., E. L. and Martin, D. J. (2020). Ballot Cues, Business Candidates, and Voter Choices in Local Elections. American Politics Research: 1-12.

[19] Campbell, R. and Cowley, P. (2014). Rich Man, Poor Man, Politician Man: Wealth Effects in a Candidate Biography Survey Experiment. The British Journal of Politics and International Relations BJPIR, 16: 56-74.

[20] Coffe, H. and Theiss-Morse, E. (2016). The Effect of Political Candidates' Occupational Background on Voters' Perceptions of and Support for Candidates. Political Science, 68 (1): 55-77.

[21] Bunkanwanicha, P. and Wiwattanakantang, Y. (2009). Big Business Owners in Politics. The Review of Financial Studies, 22 (6): 2133-2168. 